\title{
AS AMAZONAS DO NOVO MUNDO: ANÁLISE DAS FONTES LITERÁRIAS E ICONOGRÁFICAS DOS SÉCULOS XVI E XVII
}

\author{
Adriano Rodrigues de Oliveira* \\ Universidade Estadual Paulista Júlio de Mesquita Filho - UNESP \\ adrianorodriguesoliveira@gmail.com
}

\begin{abstract}
RESUMO: O artigo propõe uma análise das gravuras que ilustram as amazonas no Novo Mundo, sobretudo no decorrer do século XVI e início do século XVII. Por um lado, aborda os elementos simbólicos das imagens e, por outro, aspectos do imaginário medieval/renascentista presentes na iconografia do referido período. Além disso, o presente estudo busca explorar a relação entre o texto escrito, de diversos gêneros - narrativas de viagem, crônicas, cartas, diários, e as figuras que estampam esses mesmos conteúdos, averiguando os componentes concordantes e conflitantes na confecção do conjunto texto/imagem. Pondera ainda, a transposição do mito grego para o contexto quinhentista, enfatizando os principais ingredientes do imaginário antigo e seu ressurgimento na conjuntura do Novo Mundo.
\end{abstract}

PALAVRAS-CHAVE: amazonas - mito - iconografia- imaginário.

\section{THE AMAZONS OF THE NEW WORLD: ANALYSIS OF THE XVI AND XVII CENTURIES LITERARY AND ICONOGRAPHIC SOURCES}

ABSTRACT: The article proposes an analysis of the images that illustrate the Amazons in the New World, especially during the 16th century and beginning of the 17th century. It addresses, on the one hand, the symbolic elements of the images, and on the other, aspects of the Medieval / Renaissance imagery present in the iconography of the period. In addition, the present study seeks to explore the relationship between the written text of various genres - travel narratives, chronicles, letters, journals, and the figures that illustrate those same contents, investigating the coherent and discrepant components in the text / image set. It also considers the transposition of the Greek myth into the sixteenth-century context, emphasizing the main ingredients of the ancient imagery and its resurgence in the conjuncture of the New World.

KEYWORDS: Amazons - myth - iconography - imagery.

\footnotetext{
* Doutorando em História pela UNESP/Assis. Este artigo originou-se de pesquisas durante o mestrado e contou com o financiamento da CAPES.
} 
O mito das amazonas remonta ao imaginário da Grécia Antiga ${ }^{1}$, quando os poetas e escritores gregos anunciavam uma sociedade de mulheres guerreiras nas fronteiras do mundo conhecido.

Heródoto (485 a.C. - 425 a.C.), por exemplo, afirmou em suas Histórias, que as amazonas viviam na Cítia, uma terra inóspita situada nos limites fronteiriços do mundo helênico e que constituíam uma tribo de mulheres guerreiras, hábeis na arte de montar a cavalo, além de exímias saqueadoras. Travavam constantes combates contra os gregos, tendo como instrumentos de ataque o arco e o dardo. Desconheciam a agricultura, eram nômades, não possuíam governo ou quaisquer normas e dispensavam o matrimônio. (HERÓDOTO, 2006, p.32)

No contexto da denominada Era dos Descobrimentos, ao longo dos séculos XVI e XVII, as amazonas foram noticiadas em diversos lugares da América, por viajantes, cronistas, exploradores e caçadores de fortuna. Consequentemente, elas também se farão presentes na arte Renascentista, associadas, na maioria das vezes, a um determinado texto escrito. Acerca dessa transposição do mito clássico para o Novo Mundo, o historiador Miguel Roja Mix (2003) observa que:

O descobrimento da América significou um enorme transvasamento do imaginário europeu nas novas terras descobertas. Os mitos, as lendas, o mundo teratológico, as quimeras, tudo adquirirá carta de cidadania na América, e tudo vai ser buscado ali com afinco pelos rastreadores de fortuna e pelos caçadores de sonhos. Dessa forma, se produz um enorme deslocamento geográfico do fantástico medieval, um ressurgimento do fantástico clássico e, inclusive, um fantástico original... (ROJAS MIX, 1993, p. 125 - tradução nossa).

Dito isso, o presente artigo tem como objetivo analisar, num primeiro momento, essa transposição do mito grego para as diversas formas de narrativas de viagem, destacando os principais elementos que ressurgem ou se ressignificam no âmbito do contexto renascentista. Num segundo momento, pretende analisar os principais componentes na iconografia e sua disseminação na conjuntura quinhentista e seiscentista.

1 Compreende-se aqui como Grécia Antiga o antigo mundo grego e suas proximidades, no período de 1100 a.C. até 146 a.C. 
Em relação à abordagem teórico-metodológica, o trabalho dialoga com os estudos que, nas últimas décadas, renovaram a historiografia, inserindo as imagens como fontes e documentos importantes e necessários para a compreensão do processo histórico (BURKE, 2017, p. 17). Enfatizavam, dessa forma, a característica simbólica das gravuras, seus múltiplos sentidos e valores - reveladores da conjuntura, do imaginário e das mais diversas manifestações mentais de uma determinada época e sociedade. (SCHMITT, 2007, p. 11).

Ainda no que se refere a essa questão, Jacques Le Goff (1994) alerta que:

Essas imagens não se restringem às que se configuram na produção iconográfica e artística: englobam também o universo das imagens mentais. E se é verdade não haver pensamento sem imagem, tampouco deveremos deixar-nos afogar no oceano de um psiquismo sem limites. As imagens que interessam ao historiador são imagens coletivas, amassadas pelas vicissitudes da história, e formam--se, modificam-se, transformam-se. Exprimem-se em palavras e em temas. (LE GOFF, 1994, p. 16)

Dessa forma, compreende-se que as fontes iconográficas estão inseridas num universo mais amplo - o do imaginário - um fenômeno coletivo, social e histórico, tipicamente humano, que permeia os mais diversos campos das relações humanas: o social, o político, o econômico, o religioso, entre outros, um imaginário do qual há imagens, mentais e pictóricas, segundo o entendimento de Le Goff (1994, p. 16).

Portanto, as noções imagem/imaginário norteiam conceitualmente as discussões pertinentes ao tema proposto neste artigo e levam às seguintes interrogações: Como o texto alimenta a imagem e vice-versa? Quais os elementos clássicos e novos do mito nas fontes textuais e iconográficas? Qual a relação texto/imagem, concordâncias e discrepâncias? Essas são algumas das indagações que este trabalho pretende analisar.

\section{ASPECTOS DO MITO DAS AMAZONAS NOS RELATOS DOS VIAJANTES}

A primeira referência às amazonas da América veio dos relatos do explorador genovês Cristóvão Colombo, em sua Primeira Viagem ao Novo Mundo. Em seus Diários, consta uma citação datada, precisamente, do dia 15 de janeiro de 1493, uma terça-feira, onde afirma existir uma ilha toda povoada por mulheres sem homens (COLOMBO, 2013, p.94), e reafirma noutra citação do dia seguinte: “[...] que era certo que [elas] existiam e que, à determinada altura do ano, apareciam por ali homens da ilha 
de Caribe e, assim, se elas pariam filhos, mandavam para a ilha dos homens, e se fossem meninas, deixavam para se criarem por lá mesmo" (COLOMBO, 2013, p.96). Ainda em seus escritos, o viajante demonstra apreensão em ir " [...] onde se encontra a população de que todas essas ilhas e terra tanto medo demonstram, pois consta que com inúmeras canoas percorrem todos estes mares, comendo os homens que conseguem capturar..." (COLOMBO, 2013, p. 96)

Conforme destacou o historiador Sérgio Buarque de Holanda é provável que a descrição de Colombo sobre a referida ilha tenha vindo da leitura dos textos do aventureiro veneziano Marco Polo (1254-1324), que descreveu a Isle Femelle, onde, em certa época do ano, homens iam ter relações com certas mulheres, e por lá permaneciam durante cerca de três meses. Dos filhos gerados nesses encontros, somente as meninas ficavam sob os cuidados das mães, enquanto os meninos, após completarem a idade de 14 anos, iam para a guarda dos pais. (HOLANDA, 2010, p. 64)

A associação das amazonas a certas ilhotas remotas foi um elemento constante e emblemático no imaginário dos viajantes. Por volta de 1523, o conquistador espanhol Hernán Cortés (1485-1547), descreveu em sua Carta de Relación, uma ilha toda povoada de mulheres, sem qualquer homem, mas que apareciam por lá de tempos em tempos. Essas mulheres estariam a dez jornadas da província mexicana de Ciguatan, e eram muito ricas em pérolas e ouro. Do contato ocasional com os homens, se tinham meninos se desfaziam de sua companhia e, quando meninas, criavam-nas consigo, para que se tornassem futuras guerreiras. (CORTÉS, 1993, p. 203)

Vale ressaltar que a existência de certas ilhas míticas e fictícias não fora exclusividade do mito das amazonas, sendo elemento que atiçou a imaginação de muitos viajantes e caçadores de fortuna. No contexto dos séculos XVI e XVII era comum a menção a determinadas ilhas fantásticas, verdadeiros paraísos para tesouros fabulosos; Ilhas de Ferro, Ilhas Afortunadas, Ilhas do Ouro e da Prata. Então, os navegadores acreditavam que poderiam esbarrar a qualquer momento nessas riquezas escondidas, guardadas em segredo do mundo civilizado, um lugar onde ninguém jamais havia pisado. (DREYER-EIMBOCKE, 1992, pp. 58-59)

No caso das amazonas, o isolamento geográfico possui ainda forte conotação simbólica. É a separação brusca de dois mundos distintos. Uma sociedade de mulheres que se rebelam ao recusar o mundo dos homens, só poderia coexistir longe do progresso. Além disso, há que se considerar a imaginação fecunda dos viajantes, e a 
crença de que, nalgum lugar distante, quase que inalcançável, pudesse existir o paraíso dos prazeres, longe de qualquer restrição moral, onde conseguissem satisfazer seus desejos mais reprimidos.

No entanto, conforme observa Holanda, a difusão do mito no Novo Mundo não ficaria restrita ao plano insular, embora, tivesse conservado os traços que marcaram suas primeiras referências e mantido sua característica itinerária, deslocando-se no tempo e no espaço, acrescentando ou perdendo determinados elementos. (HOLANDA, 2010, p. 63)

Da América continental, portanto, veio o mais famoso relato sobre as amazonas americanas, por intermédio do frei dominicano Gaspar de Carvajal (15041584), espanhol a serviço do explorador Francisco de Orellana ${ }^{2}$ (1511-1546) que, no ano de 1541 embarcou numa expedição em busca de novas terras, descendo o Grande Rio acompanhado de cerca de 60 soldados. Foi durante essa expedição que o padre escreveu Descobrimento do Rio das Amazonas, um relato sobre o encontro nada amistoso entre espanhóis e guerreiras da floresta. Carvajal relata um contato pessoal, um combate em plena selva e a descrição de como seriam:

Estas mulheres são muito alvas e altas, com o cabelo muito comprido, entrançado e enrolado na cabeça. São muito membrudas e andam nuas em pelo, tapadas as suas vergonhas, com os seus arcos e flechas nas mãos, fazendo tanta guerra como dez índios. (CARVAJAL, 1941, pp. 61-62)

Aos poucos, as amazonas do Novo Mundo adquirem sua forma no imaginário dos viajantes. Muitas vezes, confundida com a figura da mulher indígena, sua nudez, seus longos cabelos, suas pernas musculosas, sua aparência irresistível que contracena com o perigo iminente. Elementos do mito grego - o isolamento geográfico, a rejeição parcial ao mundo dos homens e a afeição demasiada à arte da guerra - imbricam-se a outros elementos próprios da conjuntura colonial quinhentista: o arco e flecha, as riquezas da terra, o ouro, a prata, a aparência das índias americanas. São essas algumas das características também reproduzidas com insistência na arte renascentista.

2 Francisco de Orellana foi um explorador e corregedor espanhol que participou da conquista do Império Inca e da incursão no Rio das Amazonas (atual rio Amazonas). Um dos mais ricos conquistadores de sua época foi nomeado governador de diversas cidades do Império Espanhol quinhentista. 
Se existiam as amazonas dos confins da Europa, da África e da Ásia, deveriam existir também as da América. Esse era o argumento do cosmógrafo do rei de França, André Thevet (1502-1590) que, em Singularidades da França Antártica (1557), proclamava existirem três espécies de amazonas anteriores às do Novo Mundo. As mais antigas, segundo ele, eram as da África, com destaque para as górgones, cuja rainha foi Medusa. Uma segunda espécie teriam sido as amazonas que viveram na Cítia, nas proximidades do Rio Tanais, nas fronteiras da Grécia Antiga, tal como descreveu Heródoto em suas Histórias. Por fim, uma terceira espécie, teria vivido na Ásia, às margens do Rio Termodonte. As descendentes americanas completavam, por sua vez, o conjunto das diferentes espécies de amazonas encontradas no orbe terrestre. (THEVET, 1978, pp. 206)

Sempre suscetível a concepções extremadas, a Thevet não lhe causava espanto acreditar na existência das amazonas; no entanto, curiosamente, parecia cético em relação ao significado etimológico do termo, cuja explicação mais recorrente era o fato de as guerreiras queimarem o seio direito para melhor desempenho no combate. Sobre essa questão, o cosmógrafo emite sua opinião:

Encaro tal prática com uma certa estranheza, de vez que - pergunto aos médicos - será que tais partes do corpo poderiam ser assim tão cruelmente extirpadas que não morresse a pessoa, especialmente quando se sabe que as partes em questão são muito sensíveis e ficam próximas do coração? Não obstante, a maior parte das pessoas está de acordo com essa ideia. No caso de ser verdade, presumo que para cada moça que escapasse haveria umas cem que morreriam... (THEVET, 1978, pp. 206)

O tom extremista de Thevet retorna quando ele apresenta uma visão incomum e mórbida. Desde a Grécia Antiga, com variadas interpretações, associava-se o infanticídio às amazonas, que recusavam e matavam sua prole do sexo masculino. Porém, para Thevet, “[...] elas costumam matar os filhos homens tão logo eles sejam dados à luz, conquanto por vezes prefiram entregá-los ao presumível pai...” (THEVET, 1978, pp. 206)

A polêmica dos seios descrita por Thevet foi elemento recorrente nos textos dos viajantes e alvo de diversos relatos contraditórios. Essa questão tem suas origens no imaginário da Grécia Antiga, quando Hipócrates (460 a. C e 370 a. C), em seu tratado Sobre los Aires, Águas y Lugares, afirmava, com toda a certeza, que as amazonas 
cauterizavam o seio direito das crianças com um aparelho de bronze aquecido ao fogo. Tal prática tinha como objetivo impedir o desenvolvimento desse membro, para que, dessa forma, as futuras amazonas pudessem ser treinadas habilmente na arte da guerra. (HIPÓCRATES, 1986, p. 75)

Pelos idos de 1539, o soldado bávaro Ulrich Schmidel (1510-1580), em sua Viaje al Río de la Plata, situou, a exemplo de seus contemporâneos, a Ilha das Amazonas, fazendo questão de enfatizar o elemento do mito clássico, ao afirmar que essas mulheres só possuíam o seio direito e que queimavam o esquerdo para melhor manejar o arco nas batalhas. Das relações com os homens, que aconteciam em determinada época do ano, quando nasciam crianças do sexo masculino, devolviam-nas a seus pais e, quando meninas, criavam-nas consigo. (SCHMIDEL, 2003, p. 92-93)

Em finais da segunda metade do século XVI, um cronista oficial, o espanhol Gonzalo Fernandez de Oviedo (1478-1557), procurava explicações para o sentido etimológico da palavra e, segundo sua História General y Natural de las Indias, amaçona significava sem seio: á (sem) e maçon (teta). Para ele, os demais escritores que noticiaram as amazonas da América cometeram um equívoco, ao atribuir o significado do vocábulo a mulheres flecheiras e, dessa forma, denominar de amazona qualquer mulher indígena encontrada no Novo Mundo, enquanto, para Oviedo, as verdadeiras amazonas queimavam o seio direito e deixavam o esquerdo para alimentar suas crianças. (DE OVIEDO, 1853, p. 441)

Toda essa polêmica certamente tem uma explicação. Historicamente o seio feminino é dotado de forte conotação simbólica, muitas vezes com significados ambíguos e contraditórios. Fonte de alimento e de prazer é o símbolo da mulher. Sua ausência é a própria negação da feminilidade, embora no caso das amazonas, essa negação seja apenas parcial, já que continuavam a amamentar as crianças do sexo feminino.

Alberto Manguel observa que, desde tempos remotos, a imagem da boa mãe que alimenta seu filho opõe-se à da mãe que o destrói. Essa última é a figura da deusa Lamashtu, que se nutre da carne e do sangue dos recém-nascidos e provoca a febre puerperal e doenças nas crianças. É a representação de Medéia ou de Lady Macbeth, que retira os mamilos da boca de seu bebê e lhe espatifa os miolos. As amazonas representam essa contradição: por um lado, cumprem fielmente a imagem da mãe destruidora que recusa amamentar e cuidar de seus filhos e nalguns casos mais 
Disponível em: www.revistafenix.pro.br

extremos, cometem o infanticídio. Por outro, ao amamentar as meninas, simbolizam a imagem da boa mãe, da deusa Juno, que adota Hércules, oferecendo-lhe um dos seios. (MANGUEL, 2001, pp. 65-66)

\section{AS GRAVURAS NA EDIÇÃO dA LETTERA, POR JOANNES GRUNINGER}

A primeira alusão iconográfica ao mito das amazonas no Novo Mundo compõe-se de duas xilogravuras anônimas de uma edição alemã ilustrada da Lettera do explorador florentino Américo Vespúcio (1454-1512), publicada pelo impressor alemão Joannes Gruninger (1455-1533), na cidade de Estrasburgo, no ano de 1509.

Essa impressão de J. Gruninger apresentava algumas novidades em relação às anteriores, entre as quais a inclusão de novas ilustrações como as que serão destacadas mais adiante... (CHICANGANA-BAYONA, 2010, p. 15). Trata-se de estampas inseridas na referida edição para ilustrar um episódio narrado nas viagens de Vespúcio que envolveu alguns de seus homens e um grupo de mulheres, encontro esse que resultou na morte terrível de um jovem europeu.

A primeira xilogravura (fig. 1. A) ilustra um grupo de mulheres que saem, aparentemente, de pequenas cavernas de pedras, totalmente nuas, com seus longos cabelos encaracolados, que descem até a cintura. Percebem-se, no canto superior esquerdo da gravura, duas crianças afastadas do grupo principal. No primeiro plano, dois soldados estrangeiros, portando suas indumentárias de combate, conversam entre si, enquanto um terceiro se aproxima do grupo de mulheres.

Uma segunda xilogravura (fig. 1. B), prossegue o incidente e dá o epílogo da narrativa: três mulheres conversam e distraem o jovem europeu, enquanto uma outra se prepara para dar-lhe o fatídico golpe de estaca. No segundo plano da ilustração, outras mulheres comemoram o desfecho, sendo que uma delas entra na cabana para o preparo do iminente banquete. 


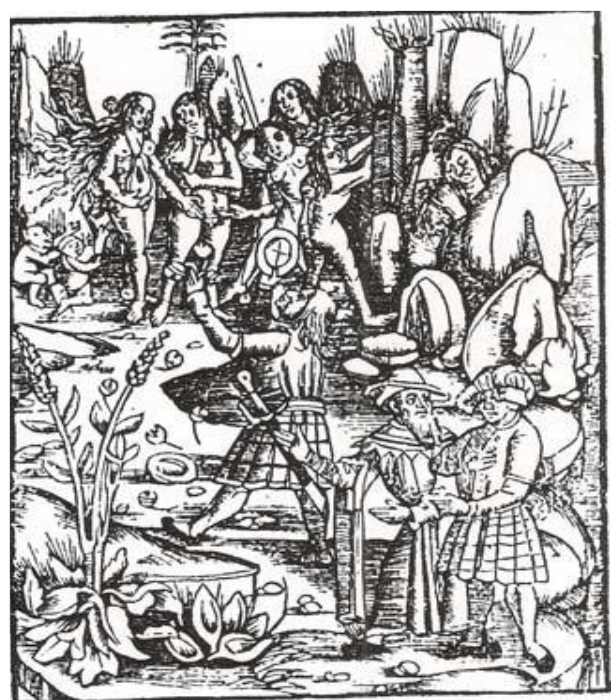

A

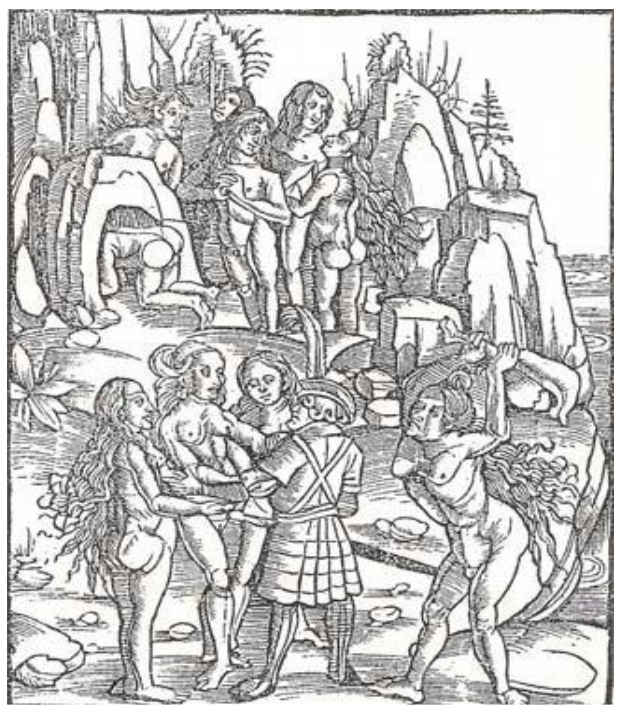

B

1. Estampas anônimas da Lettera. Edição alemã de J. Gruninger. Xilogravura, 19,5x13,5cm. Estrasburgo, 1509. Fonte: Chicangana-Bayona, Y. A. Visões de terras, canibais e gentios prodigiosos. Artcultura, v. 12, n. 21, 2010, p. 15.

O acontecimento que inspirou tais xilogravuras é descrito na Quatur Americi Vesputt i Naviationes, que narra os acontecimentos da Terceira Viagem de Vespúcio ao Novo Mundo:

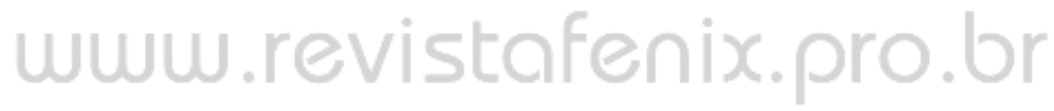

[...] dirigindo-nos outra vez à terra firme, percebemos que aquela gente trouxera consigo as mulheres. Assim que chegamos, logo enviaram muitas esposas para falar conosco, embora não estivessem inteiramente seguras a nosso respeito. Percebendo-o, concordamos em enviar até elas um de nossos jovens, que era valente e ágil, e para torná-las menos temerosas, entramos nos navios. Assim que desembarcou, misturou-se entre elas, que, circundando-o, tocavam-no e apalpavam-no, maravilhadas por ele: eis que do monte vem uma mulher portando uma grande estaca, aproxima-se do jovem e, pelas costas, deu-lhe tamanho golpe com a estaca que, imediatamente, ele caiu morto ao chão. Num instante, outras mulheres o pegaram e pelos pés arrastaram-no ao monte...todos em fuga correram de volta ao monte onde estavam as mulheres a esquartejar o jovem que haviam matado, enquanto nós olhávamos em vão, mas não era em vão que nos mostravam os pedaços que, assando num grande fogo que tinham aceso, depois comiam...(VESPÚCIO, 2003, p. 104)

O texto realça alguns elementos observados nas gravuras, como a nudez das mulheres e o perigo que elas representam. Elas eram atraentes, estavam ali prontas para serem desfrutadas, no entanto, eram traiçoeiras, perigosas, isso é o que transmitem o texto e as gravuras. 
No tocante às xilogravuras, ambas entendidas em conjunto, são bastante elucidativas, pois apresentam o enredo visual com uma clareza de detalhes, tal como se encontra no texto escrito. Nota-se que o artista teve o cuidado com a sequência narrativa, onde cada parte da gravura compõe uma sucessão de ideias imagéticas a serem anunciadas. No entanto, seria possível fazer a mesma leitura dessas imagens, sem o auxílio da comunicação escrita do texto que oferece o entendimento do contexto e de seu significado? Provavelmente, não.

Alberto Manguel (2001) destaca o novo método de observação das gravuras no Renascimento, em que a técnica da perspectiva leva a imagem da interpretação da sequência narrativa como a das modernas histórias em quadrinhos, para um congelamento da cena. A narrativa transforma-se na transmissão de símbolos, alegorias, alusões e títulos, levando o espectador a buscar o auxílio de outras fontes, sobretudo as textuais, para melhor entendimento do quadro imagético, diante do qual se encontra. É o dilema que coloca a testemunha diante da inexorável limitação da imagem - presa e emoldurada no limite espacial de um quadro - e da narrativa, dispersa, flexível e fluida na sua essência intrinsecamente temporal. (MANGUEL, 2001, p. 25)

É essa busca pelo significado que torna as ilustrações emblemáticas. Tanto a imagem na edição de J. Gruninger quanto o texto de Vespúcio, não mencionam diretamente as amazonas; trata-se de uma alusão, uma citação vaga e indireta, permitida somente por meio da associação, entre aquilo que diz a vertente clássica do mito, os textos dos viajantes e as demais imagens que reproduziram o mito na América.

Texto e imagem evocam, por sua vez, as descrições de Colombo, que poucos anos antes anunciou a ilha das mulheres sem homens, que devoravam sem piedade quem atravessasse o seu caminho. Daí em diante, o tema do canibalismo, associado ao mito das amazonas, foi, sem dúvida, uma das novidades mais marcantes da transposição do mito clássico para o Novo Mundo.

Conforme observa o antropólogo Klaas Woortmann (2014), as amazonas não eram monstros físicos, mas morais; não apresentavam anomalias senão as de comportamento e, por isso mesmo, podiam ser associadas a canibais, sendo que o canibalismo foi uma forma utilizada pelos europeus para demonizar os ameríndios (WOORTMANN, 2004, p. 91). Ainda para Woortmann, as amazonas imaginadas na América: 
Eram parte da satanização do Novo Mundo. Quando menos, representavam a desordem, uma desordem que necessitava ser conquistada. Conquistar era uma obra pia; destruir monstros era um ato de purificação, de restauração da ordem, de reunião... (WOORTMANN, 2004, p. 91)

\section{Xilogravuras em As Singularidades da FranÇa Antártica}

Em As Singularidades da França Antártica, obra publicada em Paris no ano de 1557, de autoria do cosmógrafo e frei francês André Thevet, duas xilogravuras ilustram as amazonas do Novo Mundo. Essas estampas foram inseridas no texto, para destacar uma passagem que descreve o modo como viviam as amazonas da América e os constantes combates que travavam com seus invasores. Sobre essas guerreiras americanas Thevet observa:

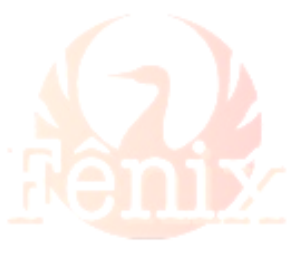

[...] vivem longe de todos, numas ilhotas que lhes servem de fortalezas, tendo como única atividade a guerra perpétua que movem contra certas tribos vizinhas, ou seja, procedendo de modo exatamente igual ao das amazonas que os historiadores descreveram. Essas belicosas amazonas americanas, isoladas e fortificadas em suas ilhas, sofrem constantes ataques por parte de seus inimigos, que alcançam suas ilhas em canoas ou outras embarcações, atacando-as sempre a flechadas. Elas, por sua vez, defendem-se corajosamente deste mesmo modo, enquanto vociferam ameaças, ululam e assumem as mais medonhas atitudes que se podem conceber. Seus escudos são feitos de cascos de tartaruga, como se pode ver na ilustração. (THEVET, 1978, p. 206)

A inclusão da referida ilustração em Singularidades, cuja autoria é questionavelmente atribuída ao gravador francês Jean Cousin (1500-1593), parece ter sido acompanhada de perto pelo próprio Thevet, conforme consta na citação acima. Essa xilogravura (fig. 2. A) apresenta a descrição imagética da epígrafe destacada anteriormente. Do seu lado esquerdo, encontra-se um grupo relativamente numeroso de mulheres, totalmente nuas, portando arco e flechas, protegidas unicamente por escudos feitos de cascos de tartarugas.

Do lado direito da mesma pintura, o perigo é iminente - um número semelhante de homens, de posse de suas armas, igualmente rudimentares, atraca com seus barcos numa espécie de ilha, enquanto travam um acirrado combate contra as amazonas. A representação gráfica em perspectiva permite-nos ver, ao fundo da gravura, uma repetição da cena do primeiro plano, indicando tratar-se de um combate simultâneo, pelejado por dezenas e talvez centenas de combatentes. 


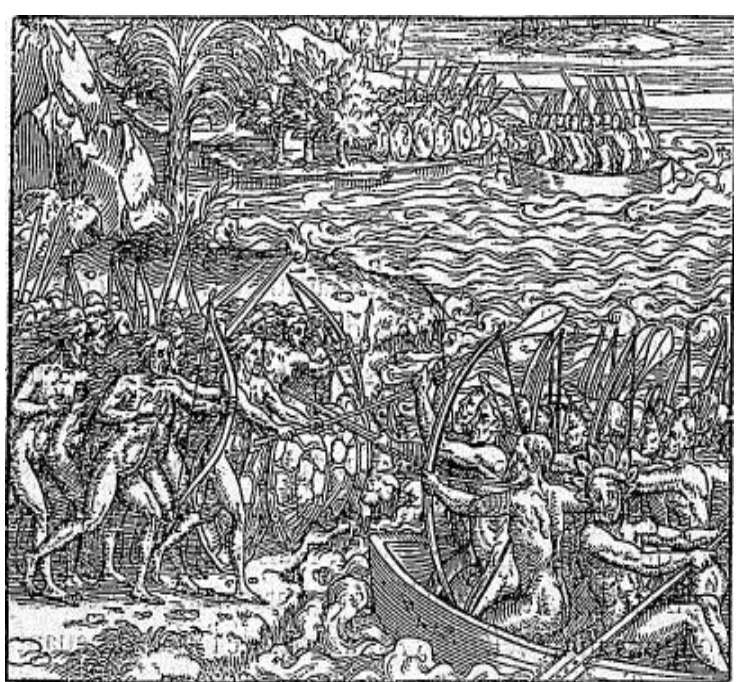

A

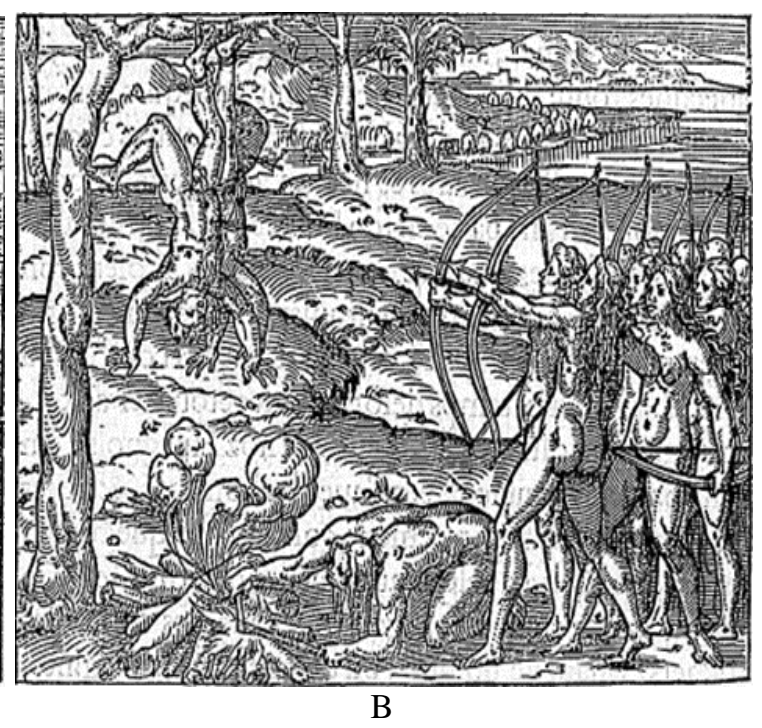

B

2. A. "Cena de batalha entre americanos e amazonas". Les Singularitez. Jean Cousin [grav.]; André Thevet, [aut. do texto]. 1558, p. 125. B. "Como as amazonas tratam aqueles que elas capturam na guerra”. Les Singularitez. Jean Cousin [grav.]; André Thévet, [aut. do texto]. 1558, p. 127. Paris (França): Biblioteca Nacional da França.

O enredo textual e iconográfico sobre as amazonas na perspectiva thevetiana não está completo em Singularidades, até a inclusão de uma segunda xilogravura (fig. 2. B), que se une à primeira em uma plenitude narrativa: dois homens, prisioneiros de guerra, encontram-se desesperadamente pendurados, presos ao galho de uma árvore; um grupo de amazonas se encarrega de flechar os inimigos, enquanto outra prepara uma fogueira sob os condenados. Ao fundo, em segundo plano, encontram-se cabanas ou fortalezas, que se perdem de vista no seio da floresta densa, tal como relata o texto. A referida gravura ilustra a citação de Thevet, que enfatiza:

Estão continuamente em guerra contra determinadas nações, e tratam mui desumanamente seus prisioneiros de guerra. Para matá-los, prendem-nos por uma perna num galho de árvore bem alto, deixando-os lá por algum tempo. De regresso, caso não tenha morrido o prisioneiro, desfecham-lhe milhares de flechadas até matá-lo. Diferentemente do procedimento dos outros selvagens, não devoram os prisioneiros mortos, preferindo queimá-los até reduzi-los a cinzas. Quando em combate, sempre avançam emitindo os mais terríveis e medonhos gritos, buscando com isso afugentar os inimigos. (THEVET, 1978, p. 208)

Simbolicamente, a ilustração realça o que os textos dos viajantes já haviam descrito sobre essas amazonas. Um mundo marcado pela oposição, um antagonismo 
gritante entre os sexos, que só se encontram por meio do embate. O modo de vida das amazonas americanas é a antítese da sociedade tida como ideal; por isso, o isolamento geográfico torna-se ainda mais emblemático. Dominá-las era conquistar a própria América, com sua beleza e perigos incontáveis.

A crueldade das amazonas, citada no texto por Thevet, constitui elemento de destaque na segunda xilogravura. A imagem da fogueira acesa debaixo dos prisioneiros de guerra realça a monstruosidade dessas guerreiras do Novo Mundo, que atiram flechas impiedosamente sobre seus contrários. Se por um lado a transcrição faz questão de enfatizar que elas não devoravam seus inimigos, a gravura não fornece ao expectador comum maiores detalhes, sugerindo que, a exemplo de outros canibais, elas talvez devorassem também, por tabela, suas pobres vítimas.

Em Singularidades, texto e imagem estão numa perfeita sintonia. As amazonas americanas, descritas e ilustradas são mulheres rudes e selvagens, incapazes de se comunicar com os homens, uma vez que só ululam, emitindo terríveis e medonhos gritos. Vivem desprovidas de qualquer luxo, habitando cavernas e cabanas, alimentam-se de peixes, frutas e certas raízes típicas da terra. Thevet afirma, de forma veemente, existirem de dez a doze mil dessas amazonas, todas inteiramente nuas, empunhando arco e flechas, que não cessavam de atirar sobre os homens que se aproximassem de seu território. (THEVET, 1978, pp.206/208)

O comportamento dessas amazonas americanas, descrito pelos viajantes e, em especial, por Thevet, estabelece-se, pois, a partir da figura da inversão. ${ }^{3}$ Elas recusam o domínio dos homens, estabelecem seu próprio governo e tratam com desumanidade seus prisioneiros de guerra. Além disso, recusam o matrimônio e, em menor escala a maternidade, já que a recusa dessa se dá tão somente com a prole do sexo masculino. São mulheres ao avesso, que abandonam as atividades domésticas para se dedicar única e exclusivamente à atividade da guerra.

Sobre essa inversão o historiador Frank Lestringrant (2009) observa que:

Para François Hartog (2014), a inversão constitui-se de uma estratégia de tradução utilizada nas narrativas de viagem, onde o narrador, para traduzir a diferença em relação ao Outro, vale-se da comparação e da analogia, onde "[...] a alteridade se transcreve como um antipróprio". (HARTOG, 2014, p. 243) 
Disponível em: www.revistafenix.pro.br

Tal é o Topos do mundo invertido, tão frequentemente ilustrado no século XVI, e cujo 'complexo' das amazonas seria uma das variantes particulares, ele estigmatiza a desordem presente pela imagem de uma viravolta hiperbólica e pede - por esse recurso à figura escandalosa da inversão - o retorno à ordem tradicional das coisas. (LESTRINGANT, 2009, p.144)

\section{O TEXTO DE Sir WALTER RALEIGH E AS GRAVURAS NA EDIÇÃO DE LEVINUS HULSIUS}

Uma das páginas mais emblemáticas da reprodução iconográfica do mito das amazonas no Novo Mundo teve início na saga de A Descoberta do Grande, Belo e Rico Império da Guiana, uma epopeia escrita em 1595, do gênero denominado narrativa de viagem, publicada em 1596, num calhamaço de 101 folhas, pelo editor Robert Robinson, de Londres. O autor dessa narrativa, o inglês Sir Walter Raleigh (15521618), foi poeta, soldado, político, pirata e cortesão, personagem notória e controversa do círculo de protegidos da rainha Elizabeth I (1558-1603).

Sua obra contribuiu para que, já no apagar das luzes do século XVI, o mito das amazonas continuasse ativo no imaginário dos viajantes e fosse ilustrado por artistas e cartógrafos do mesmo período.

Raleigh, que pretendia recuperar seu antigo prestígio diante da rainha da Inglaterra ${ }^{4}$, descreveu em tom heroico os percalços de sua estadia na Guiana, os embates com os espanhóis, (que também disputavam esse território), as disputas religiosas entre católicos e protestantes e, acima de tudo, as maravilhas daquela região, seus habitantes, sua fauna, a flora, seres e lugares fantásticos. Sobre as amazonas ele faz as seguintes observações:

[...]. As mulheres guerreiras das tribos próximas à Guiana só conviveriam com homens uma vez por ano. Então, bebiam, fumavam, dançavam, lutavam e fornicavam sem parar durante um mês inteiro, que acredito ser abril. Em abril, não só as amazonas, mas todos os chefes, príncipes e sábios das tribos da região se reúnem num tipo de festival [...]. Depois das cerimônias para promoções e premiações dos melhores da tribo, as amazonas visitavam outras nações amigas. Eram recebidas com honras militares, inspecionavam os batalhões e

4 Prestígio perdido, após casar-se com uma dama de companhia da rainha, sem a sua autorização, sendo retirado de suas funções palacianas e trancafiado na torre de Londres. O escritor e tradutor Eduardo San Martin, afirma que Raleigh, após sua liberdade, pretendia encontrar o Eldorado, fazer uma generosa doação à coroa e reconquistar as graças da rainha. (MARTIN, 2002, p. 16) 
Disponível em: www.revistafenix.pro.br

escolhiam seus machos preferidos, de quem não se separavam até surgir a lua nova. (RALEIGH, 2002, pp. 62/65)

A obra de Raleigh foi posteriormente editada pelo belga Levinus Hulsius (1546-1606), um comerciante de instrumentos científicos, impressor e lexicógrafo oriundo de Flandres, que viveu e trabalhou na Holanda e Alemanha. Hulsius fez uma série de publicações da obra original, datadas da passagem do século XVI para o XVII, em que tratou de inserir novas gravuras no texto, entre as quais ilustrações sobre as amazonas da Guiana.

A primeira dessas xilogravuras ilustra o festival descrito por Raleigh, e apresenta um número relativamente grande de amazonas, junto a uma quantidade ligeiramente menor de homens. Ambos os gêneros dançam, banqueteiam, trocam carícias e fornicam. A cena é emblemática, e destaca o único momento possível do encontro entre os sexos, onde as terríveis amazonas se juntam a homens de regiões vizinhas com o objetivo principal da procriação. No canto superior esquerdo do primeiro plano da gravura, duas amazonas armadas de arco e flechas, típicos instrumentos de guerra, protegem atentamente o festival erótico (fig. 3).

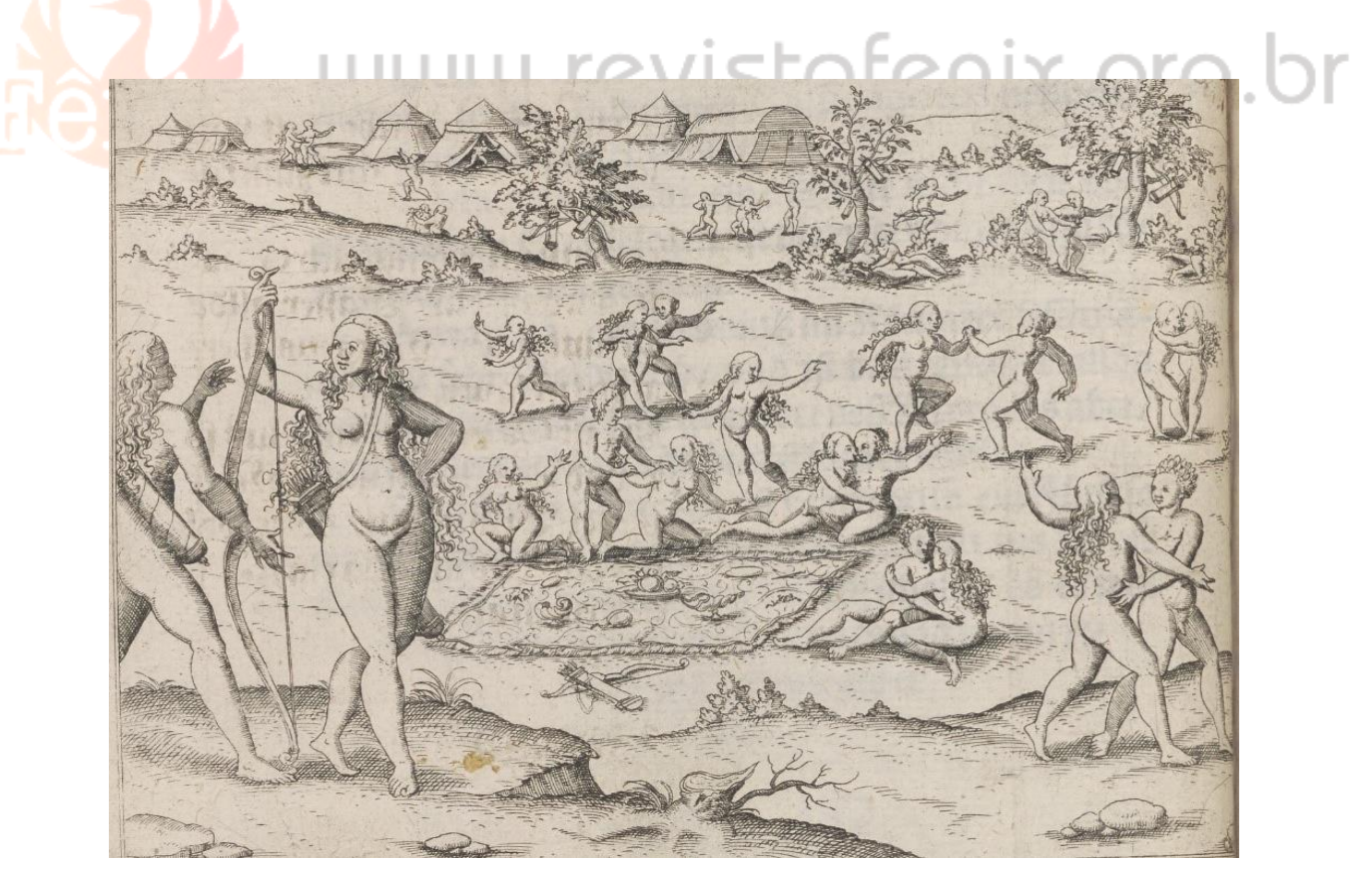

3. O banquete festivo das amazonas que acontecia durante o mês de abril. Por Levinus Hulsius, para o livro de Walter Raleigh. Quarta edição, 1612. FONTE: Biblioteca da Universidade de Virgínia.

Nota-se que o artista teve a clara intenção de criar uma imagem que corroborasse a descrição textual destacada na citação de Raleigh, enfatizando determinados elementos: a nudez, o erotismo, a selvageria, o ritual festivo e 
pecaminoso. Qual o significado da cena aos olhos do espectador comum no contexto de propagação dessa gravura? Antes de tudo, é preciso compreender o simbolismo do erotismo no Renascimento que, por meio da difusão de imagens, tinha no ato sexual a sua "pedra de toque". (MORAES, 2003, p. 4)

Para a Igreja, o sexo era um "esforço" necessário para procriação, não devia ser praticado por prazer, mas em função da família, da linhagem, uma vez que o pecado e a fornicação tinham que ser evitados. Maior encargo recaía sobre as mulheres, que deviam ser boas mães, conformadas e restritas à esfera doméstica. Consequentemente, o espaço familiar não reservava lugar para o erotismo, que só poderia ser praticado fora de seus domínios, ou seja, através da relação extraconjugal. Como contraponto, a recorrente difusão de gravuras destacando temas eróticos, funcionava como uma forma de protesto contra a repressão sexual, a arte como expressão das necessidades não atendidas. (RASPANTI, 2018)

Mary Del Priore (2015) enfatiza que o corpo feminino no Renascimento era caracterizado pelos mais mórbidos extremismos. A mulher era considerada um agente de Satã, seu corpo, um vaso do Diabo, era ali que ele podia operar suas obras, por intermédio da sexualidade. Por conseguinte: "Como a mulher era considerada por natureza um agente de Satã, toda a sua sexualidade podia prestar-se à feitiçaria, como se seu corpo, ungido pelo mal, correspondesse às intenções malignas de seu senhor". (DEL PRIORE, 2015, p. 112)

Essa é a principal mensagem da xilogravura de Hulsius. As amazonas da América representam a antítese da sociedade estabelecida, pois rompem com a ordem, com os princípios morais e religiosos de uma Europa cristã. Uma sociedade governada por mulheres só poderia resultar no caos, na desordem, numa inversão total do status social vigente. Ao mesmo tempo, a sociedade das amazonas é o desejo reprimido, o paraíso perdido, que está ali para ser encontrado, explorado e desfrutado pelo conquistador.

Os longos cabelos das amazonas, seu corpo atraente, a existência de ambos os seios - característica realçada nas gravuras e que diverge dos textos, representam a sedução, o convite para a tentação que se encontra no caminho dos viajantes, exploradores ou caçadores de fortuna. O cabelo, historicamente carregado de simbolismos é a aproximação do ser à natureza, à animalidade, ao pecado, ao sexo e à 
Disponível em: www.revistafenix.pro.br

feminilidade (PERROT, 2013, pp.54-55) . O corpo atraente simbolizando a tentação e a sedução será reproduzido com insistência pelos artistas do Renascimento.

O corpo, o cabelo, a nudez, o arco e flechas são elementos que ressurgem noutra gravura da mesma edição de Hulsius. Nela, uma amazona está ilustrada como uma típica mulher indígena. Na sua mão direita carrega uma flecha, enquanto segura um potente arco na sua mão esquerda. Às suas costas carrega uma aljava repleta de flechas, enquanto seus longos cabelos enrolados descem até a altura da cintura. Ao fundo da xilogravura, vê-se um tatu, animal natural da terra, além de uma cadeia de montanhas que se prolonga ao longo do horizonte (fig. 4).

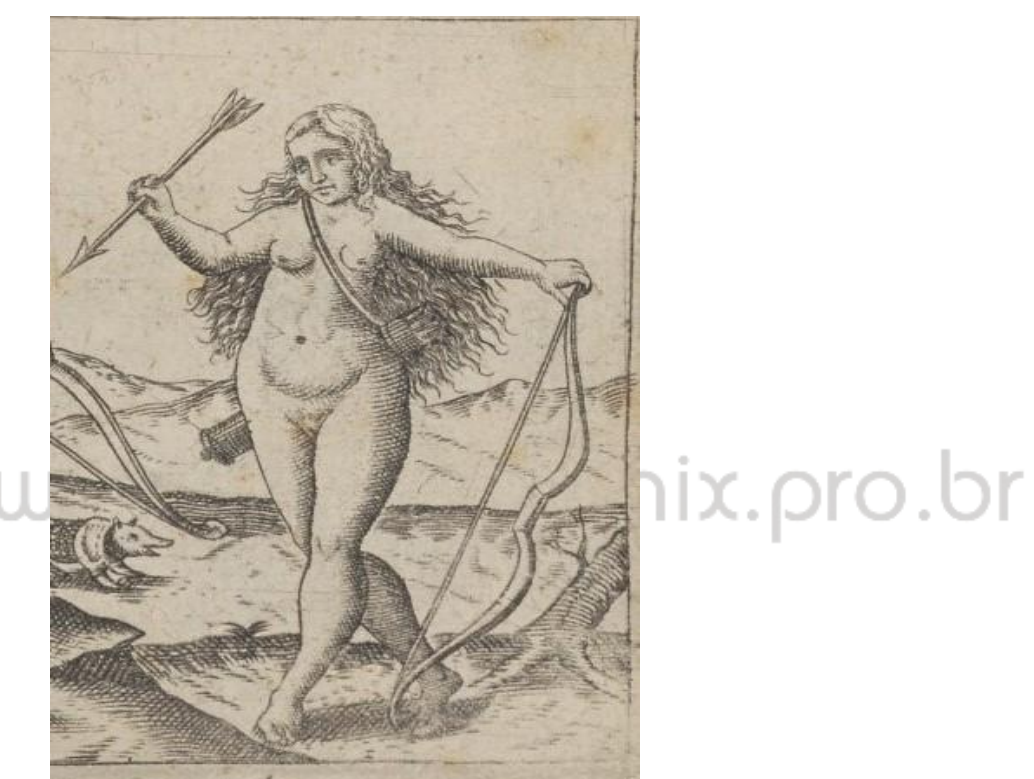

4. Típica amazona americana com seu arco e flechas. Por Levinus Hulsius para o livro de Sir Walter Raleigh. Quarta edição, 1612. Fonte: Biblioteca da Universidade de Virgínia.

Não restam dúvidas de que a imagem acima se refere a uma amazona, conforme consta no relato de Raleigh em Descobrimento da Guiana. Entretanto, essa seria uma das últimas a representar o mito icônico em terras da América, fazendo com que as amazonas tivessem vida relativamente curta no Novo Mundo, no que diz respeito à sua reprodução iconográfica, conforme observou Roja Mix (1993, p. 137). A partir do século XVII, as temidas guerreiras, anunciadas com afinco pelos viajantes, se transformariam na própria alegoria no continente americano. Sobre essa questão, que merece um estudo a parte, Del Priore observa que: 
Fênix - Revista de História e Estudos Culturais

Janeiro -Junho de 2020 Vol.17 Ano XVII no 1 ISSN: $1807-6971$

Disponível em: www.revistafenix.pro.br

A América é uma mulher [...]. Pelo menos assim ela aparece na iconografia entre os séculos XVI e XVIII; o ventre opulento, o longo cabelo amarrado com conchas e plumas, as pernas musculosas, nus os seios [...] A representação assim construída pelos europeus traduzia um discurso que tentava se impor como concepção social sobre o Novo Mundo: a América, como uma bela e perigosa mulher, tinha que ser vencida e domesticada para ser melhor explorada (DEL PRIORE, 1992, p. 149).

\section{CONSIDERAÇÕES FINAIS}

O presente artigo teve como objetivo analisar a reprodução do mito das amazonas no Novo Mundo, a partir de dois tipos de fontes: Em primeiro lugar, a produção textual, isto é, a denominada literatura de viagem - relatos, crônicas, diários de bordo, relações, entre outros. Um segundo tipo de fonte são as imagens, especialmente xilogravuras, na maioria das vezes inseridas no texto, propositalmente, para dar destaque e fazer uma menção direta às amazonas.

Com a proposta de analisar os principais elementos simbólicos do mito chegou-se à seguinte conclusão. Em relação aos textos, percebeu-se que, na transposição do mito clássico para o Novo Mundo, houve manutenção e perda de diversos desses componentes. Tal como no mundo antigo, os relatos dos viajantes não economizaram em descrever as amazonas como uma sociedade de mulheres guerreiras, que recusavam o domínio dos homens. Eram atraentes, perigosas, que tratavam de forma cruel seus invasores, e habitavam, quase sempre, uma ilha, ou terra incógnita. Cortavam um dos seios, e da relação ocasional com os homens, só criavam a prole do sexo feminino.

No entanto, foi, sobretudo, da arte, que vieram as maiores novidades em relação ao seu ressurgimento na América. A aparência das índias americanas, com ambos os seios fartos, o arco e flechas, a nudez do corpo, os longos cabelos, são algumas das características reproduzidas com insistência na iconografia do período. Interessa, pois, perceber, como o imaginário acerca das amazonas percorreu um período histórico de longa duração, tornando-se fluído no tempo e no espaço.

Conclui-se, da análise textual e imagética, que as amazonas do Novo Mundo representavam mais que uma mera transposição para um novo espaço geográfico. Na América, o mito encontrou terreno fértil para disseminar o imaginário europeu acerca dos povos ameríndios. As amazonas simbolizavam a antítese da sociedade considerada ideal, uma oposição marcante, que precisava ser dominada e conquistada. 


\section{REFERÊNCIAS BIBLIOGRÁFICAS}

BURKE, Peter. Testemunha ocular: O uso de imagens como evidência histórica. São Paulo: Editora Unesp, 2017.

CARVAJAL, Gaspar de. Descobrimento do rio das Amazonas. Trad. C. de Mello

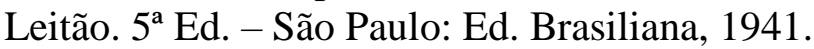

COLOMBO, Cristóvão, 1450-1506. Diários da descoberta da América: as quatro viagens e o testamento/Cristóvão Colombo. Trad. de Milton Persson. Porto Alegre: L\&PM, 2013.

CORTÉS, Hernan. Cartas de relación. Clásicos Castalia; Edición, introducción y notas de Ángel Delgado Gómez. Madrid: Castalia, 1993.

CHICANGANA-BAYONA, Yobenj Aucardo. Visões de terras, canibais e gentios prodigiosos. Artcultura, v. 12, n. 21, 2010.

DE OVIEDO, Gonzalo Fernández et al. Historia general y natural de las Indias. Madrid: Ed. la Real Academia de la Historia, 1853.

DEL RIPORE, Mary. Magia e medicina na colônia: o corpo feminino. In: História das mulheres no Brasil. São Paulo: Editora Contexto. 2015.

DREYER-EIMBOCKE, Oswald. O descobrimento da terra. Trad. de Alfred Josef Keller. São Paulo: Melhoramentos/Editora da Universidade de São Paulo, 1992.

HARTOG, François. O Espelho de Heródoto: ensaio sobre a representação do outro. 2. ed. Belo Horizonte: Editora UFMG, 2014.

HERÓDOTO. História. Versão para o português de J. Brito Broca. EBooksBrasil, 2006. Disponível em: http://www.ebooksbrasil.org/adobeebook/historiaherodoto.pdf. Acesso em: 30/10/18.

HIPÓCRATES. Tratados Hipocráticos. Livro II. Sobre Los Aires, Aguas y Lugares. Madrid: Ed. Gredos, 1986.

HOLANDA, Sérgio Buarque de. Visão do Paraíso: os motivos edênicos no descobrimento e colonização do Brasil. São Paulo: Companhia das Letras, 2010.

LE GOFF, Jacques. O imaginário medieval. Lisboa: Estampa, 1994.

LESTRINGANT, Frank. A oficina do cosmógrafo ou a imagem do mundo no Renascimento. Rio de Janeiro: Civilização Brasileira, 2009.

MANGUEL, Alberto. Lendo imagens: uma história de amor e ódio. São Paulo: Companhia das Letras, 2001.

MARTIN, E. San. Walter Raleigh, A Descoberta da Guiana e o Mito de Eldorado. Prefácio. In: Diário de Walter Raleigh - O caminho de Eldorado. A descoberta da Guiana por Walter Raleigh em 1595. Adaptação e notas de E. San Martin. Porto Alegre: Artes e Ofícios, 2002.

MORAES, Eliane Robert. O efeito obsceno. Cadernos Pagu (20), Campinas-SP, Núcleo de Estudos de Gênero-Pagu/Unicamp, 2003, p.121-130.

PERROT, Michele. Minha história das mulheres. São Paulo: Contexto, 2013.

Disponível em: http://www.scielo.br/pdf/cpa/n20/n20a04.pdf-Acesso em: 04. Out. 2018.

RALEIGH, Walter. O caminho do Eldorado. A descoberta da Guiana por Walter Raleigh em 1595. Adaptação e notas de E. San Martin. Porto Alegre: Artes e Ofícios, 2002.

RASPANTI, Márcia Pinna. Casamento, fornicação e erotismo. Disponível em: https://historiahoje.com/casamento-fornicacao-e-erotismo/. Acesso em: 26.set. 2018. 
ROJAS MIX, Miguel. "Los monstruos: ¿mitos de legitimación de la conquista? América Latina: palavra, literatura e cultura, v. 1, p. 123-150, 1993.

SCHMIDEL, Ulrich. Viaje al río de la Plata. Biblioteca Virtual Universal, 2003, p. 9293. Disponível em: http://www.biblioteca.org.ar/libros/10069.pdf Acesso em: 24 jan. de 2019.

SCHMITT, Jean-Claude. O corpo das imagens: ensaio sobre a cultura visual na Idade Média. Bauru, SP: Edusc, 2007.

THEVET, André. As singularidades da França Antártica. Trad. de Eugênio Amado. São Paulo: Ed. da Universidade de São Paulo, 1978.

VESPÚCIO, Américo. Novo Mundo: as cartas que batizaram a América. Apresentação e notas de Eduardo Bueno. São Paulo: Ed. Planeta do Brasil, 2003.

THEVET, André. As Singularidades da França Antártica. Trad. de Eugênio Amado. São Paulo: Ed. da Universidade de São Paulo, 1978.

WOORTMANN, Klaas. O selvagem e o Novo Mundo: Ameríndios, humanismo e escatologia. Brasília: Editora UnB, 2004. 